\title{
Idiopathic Anaphylaxis: a Perplexing Diagnostic Challenge for Allergists
}

\author{
Theo Gulen ${ }^{1,2,3}$ - Cem Akin ${ }^{4}$
}

Accepted: 8 January 2021 / Published online: 9 February 2021

(C) The Author(s) 2021

\begin{abstract}
Purpose of Review The aim of this systematic review is to present the proposed theories of pathogenesis for idiopathic anaphylaxis (IA), to discuss its classification, its diagnostic approach, and management.

Recent Findings IA represents a major diagnostic challenge and is diagnosed when excluding the possible identifiable triggers of anaphylaxis. The current research, however, revealed that certain conditions including mastocytosis, mast cell activation syndromes, and hereditary alpha tryptasemia can masquerade and overlap with its symptomatology. Also, newly identified galactose-alpha-1,3-galactose mammalian red meat allergy has recently been recognized as underlying cause of anaphylaxis in some cases that were previously considered as IA.

Summary IA comprises a heterogenous group of conditions where, in some cases, inherently dysfunctional mast cells play a role in pathogenesis. The standard trigger avoidance strategies are ineffective, and episodes are unpredictable. Therefore, prompt recognition and treatment as well as prophylaxis are critical. The patients should always carry an epinephrine autoinjector.
\end{abstract}

Keywords Anaphylaxis $\cdot$ Mast cells $\cdot$ Idiopathic anaphylaxis $\cdot$ Tryptase $\cdot$ Mast cell activation $\cdot$ Mastocytosis

\section{Introduction}

Mast cells (MCs) are granulated, tissue-dwelling multifunctional effector cells that are normally found in almost all tissues [1-3]. MCs constitutively display a range of biologically active receptors including high-affinity receptors for $\mathrm{IgE}$, (FceRI), and surface $\mathrm{G}$ protein-coupled receptors including recently reported Mas-related G protein receptor (MRGPRX2), which can be

This article is part of the Topical Collection on Anaphylaxis and Drug Allergy

Theo Gulen

Theo.Gulen@ki.se

1 Department of Respiratory Medicine and Allergy, K85, Karolinska University Hospital, Huddinge, SE-141 86 Stockholm, Sweden

2 Immunology and Allergy Unit, Department of Medicine Solna, Karolinska Institutet and Karolinska University Hospital, Stockholm, Sweden

3 Mastocytosis Center Karolinska, Karolinska Institutet and Karolinska University Hospital, Stockholm, Sweden

4 Division of Allergy and Clinical Immunology, Department of Internal Medicine, University of Michigan Health System, Ann Arbor, MI, USA activated through non-IgE pathways by small molecules, including certain drugs [4-7]. Upon activation, these cells degranulate and release a large array of pro-inflammatory and vasoactive mediators and signaling molecules including histamine, prostaglandins, and leukotrienes [7, 8].

Anaphylaxis is the most severe systemic hypersensitivity reaction, and MCs appear to be the primary effector cells for driving anaphylaxis in humans as increased levels of mast cell mediators such as tryptase and histamine have been detectable during episodes. Additionally, basophils may theoretically contribute to symptom development, when activated, by secreting mediators including histamine and $\mathrm{LTC}_{4}$. To date, no specific biomarker has been identified to predict patients at risk, to stratify severity of reactions or to optimize management.

Food, drugs, and stinging insects represent the most commonly identified triggers of anaphylaxis. However, in certain patients with anaphylaxis, no eliciting factor can be identified despite a comprehensive allergy workup, and therefore, the term "idiopathic anaphylaxis" (IA) was introduced. IA was first described by Bacal and colleagues in 1978 in a report of 11 patients whose episodes could not be explained by a known trigger [9]. IA is a phenotype of anaphylaxis, and clinically, the presentation is similar to that of other types of anaphylaxis. It is caused by recurrent episodes of mediator-related 
multiorgan symptoms (at least 2 organ involvement) presenting with various combinations of urticaria, angioedema, laryngeal tightness, bronchoconstriction, dyspnea, hypoxia, abdominal pain, nausea, vomiting, diarrhea, hypotension, and syncope [10]. In rare cases, the IA episodes may lead to death due to the cardiovascular collapse.

The recent research exposed that IA can masquerade as an underlying mast cell dysfunction leading to uncontrolled mast cell activation, presumably by lowered mediator release threshold [11••, 12, 13•]. As our understanding of mast cell disorders continues to grow, the classification for these disorders evolves. The purpose of this article is, therefore, to discuss the pathogenesis of IA within the broader context of mast cell activation disorders as wells as reviewing its epidemiology, clinical manifestations, and diagnosis.

\section{Epidemiology}

The available epidemiological data about the exact prevalence and incidence of anaphylaxis are limited and often inconsistent. However, it is widely accepted that anaphylaxis is a relatively rare condition. With these limitations, the lifetime prevalence of anaphylaxis in the general population has been estimated to be between 0.3 and $1.6 \%[14,15]$.

Nevertheless, the actual incidence and prevalence of IA are difficult to estimate, since its prevalence varied among different reports. This is probably due to using different definitions or diagnostic criteria (not applying consensus criteria before 2006), diagnostic limitations in older studies, for instance overlooked mast cell disorders, and possible over-diagnosing of IA by emergency departments. However, one indirect approach to estimate its incidence is to use the percentage of anaphylaxis cases presenting to an allergist/immunologist that remained idiopathic despite extensive evaluation [16]. By this means, between 20,592 and 47,024 total cases of IA have been reported in the USA, thereby the prevalence was estimated approximately 1 in 10,000 in the mid-1990s $[16,17]$. Consequently, approximately $30-60 \%$ of cases of anaphylaxis in adults and $10 \%$ of cases in children are deemed idiopathic after an extensive evaluation [18-20]. Additionally, there is a higher incidence of IA in women than in men and a higher incidence in adults than in children [20-22]. It was also reported that patients with IA also have a high rate of atopy, approximately $50 \%$ [21, 23]. Consequently, larger populations studies are needed to determine the true prevalence, incidence, and demographics of IA.

\section{Pathogenesis}

The underlying mechanisms leading to idiopathic anaphylaxis are not fully understood, although various theories were proposed to explain pathogenesis. One possible theory for IA involves elevated numbers of activated lymphocytes. IA patients have been shown to have a higher percentage of activated $\mathrm{T}$ cells (defined as $\mathrm{CD}^{+} \mathrm{HLA}^{+} \mathrm{DR}^{+}$) in their blood during acute episodes compared to baseline levels [24]. Moreover, IA patients also have more activated B cells $\left(\mathrm{CD} 19^{+} \mathrm{CD}^{+} 3^{+}\right)$during both acute episodes and at baseline compared to control patients or patients with chronic idiopathic urticaria [24]. Interestingly, another study reported that soluble CD25 levels were higher in patients with anaphylaxis after an acute episode compared to healthy controls but were lower than mastocytosis patients [25]. Although this may provide further support for $\mathrm{T}$ cell activation involvement in anaphylaxis process, the role played by activated T- and/or Blymphocytes in the pathogenesis of IA or interaction of these cells with $\mathrm{MC}$ and basophils remains elusive. Additionally, due to the fact that females are more often diagnosed with IA, a potential effect of female hormones on $\mathrm{MC}$ or basophils has been proposed [26, 27]. Nonetheless, no difference has been shown regarding basophil activation in IA patients compared to controls. Gene expression profiles in patients with IA were compared to nonatopic controls by DNA microarray analyses in a study which found that cells from patients with IA differentially expressed genes correlating with the level of CD203c, and among these genes, some were involved in regulation of mast cell/basophil degranulation [28].

Another attractive theory of IA pathogenesis suggests increased activation of mast cells in IA patients. This is due to the hypothesis that IA patients have hyperreactive mast cells that are prone to degranulation because of the presence of extracellular Th2 cytokines [17]. This hypothesis was supported by the findings that IA patients were found to have increased levels of IL-4, IL-5, and IL-13 cytokines after lymphocyte stimulation compared to atopic subjects and healthy controls [29]. However, in a prospective study of patients with IA, ex vivo studies of cultured mast cells indicated no evidence of a hyperreponsive mast cell phenotype, when tested for IgE-mediated release of beta-hexosaminidase [13•]. Nevertheless, other mechanisms have not been specifically studied. Interestingly, the investigators did note that peripheral blood from patients with IA yielded higher mast cell numbers in culture compared to healthy controls [13•] supporting the notion that MCs have multiple other mechanisms for activation.

Moreover, there are further supporting data that IA is as a mast cell activation disorder [30-33]. First, the predominant cell type known to cause anaphylaxis in humans is the mast cell. It should be noted that although non-mast-cell-dependent anaphylaxis has been reported in mice and is thought to be caused by activation of myeloid cells such as neutrophils and macrophages [34, 35]. However, to the best of our knowledge, this phenomenon has not been proven in humans. Second, elevated tryptase levels during an acute IA episode support 
mast cell degranulation [33, 36, 37]. Third, patients improve with mast cell-directed therapy including antihistamines, cysteinyl leukotriene receptor antagonists, and corticosteroids $[19,22,38]$. Therefore, human disorders involving anaphylaxis are thought to be predominantly mast cell dependent.

\section{Idiopathic Anaphylaxis in the Context of Mast Cell Activation Disorders}

The nomenclature and classification of mast cell disorders has evolved during the recent years as our knowledge continuously increased on these disorders. For instance, mastocytosis is a clonal mast cell disorder and previously the proliferation and accumulation of abnormal MC in different organs has been emphasized as a typical characteristic of this condition [39, 40]. However, the research during the last decade recognized that activation of $\mathrm{MC}$ in mastocytosis is equally important since patients with systemic mastocytosis (SM) have a higher risk for an excessive mediator release leading to severe anaphylaxis $[41,42]$. Therefore, a new nomenclature has been proposed to encompass all current diagnoses regarding mast cell disorders and the term mast cell activation syndrome (MCAS) has been introduced [43-45].

Three sets of criteria are required to fulfill MCAS diagnosis: typical episodic symptoms which are attributable to mast cell activation, objective laboratory evidence of mast cell involvement by confirming a substantial transient increase in validated mast cell mediators in the serum (preferably, at least $20 \%$ increase in serum tryptase levels plus $2 \mathrm{ng} / \mathrm{ml}$ within $4 \mathrm{~h}$ of acute episode) or in the urine, and control of symptoms with mast cell-directed therapies [45]. Once a diagnosis of MCAS has been confirmed, further classification is necessary. Accordingly, MCAS have been classified into three types. Primary MCAS, that is associated with clonal mast cell disorders, comprise monoclonal MCAS and mastocytosis, which are characterized by underlying intrinsic mast cell defects, such as tyrosine kinase KIT mutation (D816V) or alterations in enzymes or expression of aberrant $\mathrm{MC}$ receptors including $\mathrm{CD} 25$, that, in turn, confer higher risks for uncontrolled mast cell activation. Diagnosis of clonal MCAS can only be made after an extracutaneous biopsy, most often after a bone marrow biopsy [39, 40]. Additionally, clonal MCAS can present with the clinical manifestations of IA $[11 \bullet \bullet, 12,46]$.

Secondary MCAS results in symptoms of mast cell activation through IgE and non-IgE-mediated processes, such as food-, drug-, or Hymenoptera venom-induced severe anaphylaxis. Finally, idiopathic MCAS results in mast cell activation symptoms without a clear precipitating etiology. Patients with IA are the epitome of idiopathic MCAS; therefore, it is essential to evaluate whether the patient meets criteria for IA (Fig. 1). However, idiopathic MCAS is a broader entity and may also include patients whose episodes may not fulfill the clinical criteria of idiopathic anaphylaxis, such as patients presenting with concomitant skin and gastrointestinal symptoms.

\section{Clinical Criteria for Anaphylaxis}

Lack of globally recognized definition of anaphylaxis has long caused failure to diagnose and delayed treatment in patients and also hampered research efforts. Subsequently, multinational, multidisciplinary symposia were convened to achieve a true international consensus on the clinical criteria for the diagnosis of anaphylaxis [10].

Signs and symptoms of anaphylaxis are generally related to the cutaneous, gastrointestinal, respiratory, and cardiovascular systems, and the diagnosis requires concurrent occurrence of minimum 2 organ systems. The required organ system involvement also varies depending upon whether there is a "likely" or "known" trigger for the actual patient. For instance, combination of symptoms by the involvement of the skinmucosal tissue and gastrointestinal tract can be considered anaphylaxis in context of food allergies, if there is a "likely" trigger for the patient. Exceptionally, in context of confirmed allergy, for instance venom or drug, the related patients can develop anaphylaxis only by cardiovascular system involvement (drop in blood pressure or syncope) after re-exposure. Additionally, even when the allergic status of the patient is unknown or there is no likely cause of the reactions, as in idiopathic anaphylaxis, when the onset of illness is acute (minutes to several hours), a diagnosis of anaphylaxis can be made when either reduced blood pressure (or associated symptoms of end-organ dysfunction, such as syncope) and/ or respiratory compromise or laryngeal edema are present accompanied by the involvement of the skin-mucosal tissue symptoms [10]. Figure 1 illustrates the clinical criteria of both IA and MCAS.

The clinical manifestations of IA were reviewed in a series of 335 patients [19]. Interestingly, all had experienced angioedema and urticaria in this study. In addition, $63 \%$ experienced upper airway obstruction, 39\% bronchospasm, 23\% hypotension or syncope, and $22 \%$ gastrointestinal symptoms [19]. Isolated cardiovascular collapse was not reported in these series. Notably, clonal MCAS patients presenting with IA may more prevalently suffer from cardiovascular symptoms, as it was reported to be over $90 \%$ in a study [12]. Table 1 demonstrates organ-based symptoms of idiopathic anaphylaxis attributable to release of mast cell mediators.

\section{Diagnostic Approaches and Differential Diagnosis}

The differential diagnosis of IA is broad and includes among others all causes of anaphylaxis such as food, hymenoptera 
Fig. 1 The criteria of idiopathic anaphylaxis versus mast cell activation syndrome.

Figure modified from references $[10,40]$. Note that when there is no likely cause of the reactions, if the onset of illness is acute, a diagnosis of idiopathic anaphylaxis can only be made when either reduced blood pressure (or its symptoms such as syncope) and/or respiratory compromise are present accompanied by the involvement of the skinmucosal tissue symptoms. Please see the text for more discussion
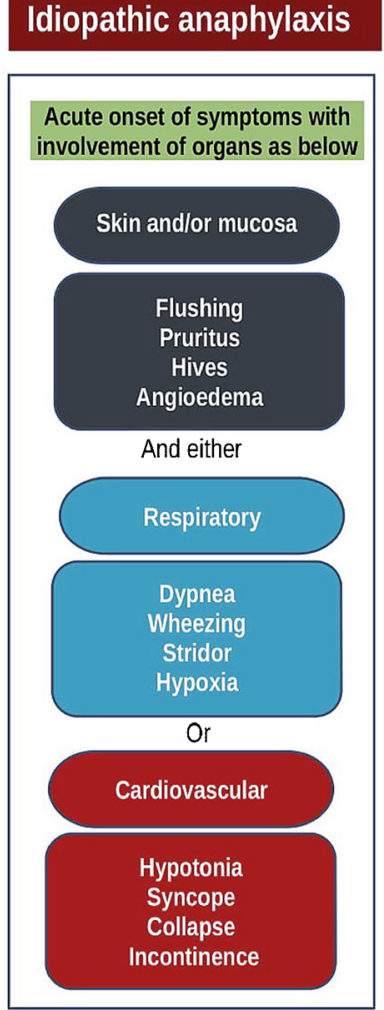

\section{MCAS Clinical Criterion}

Acute onset of symptoms with concurrent involvement of minimum 2 of the 5 organ systems as below

Skin and/or mucosa

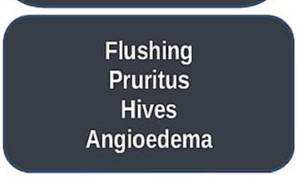

Angioedem
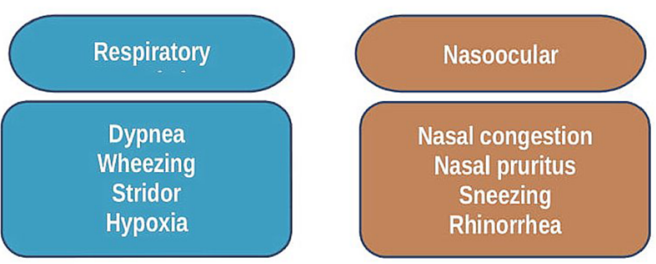

Cardiovascular

Hypotonia

Syncope

Collapse

Incontinence venom, drugs, and exercise. Other allergic conditions such as acute urticaria and/or angioedema, acute asthma episodes involve a single organ system but may mimic anaphylaxis. Additionally, some endocrine (such as pheochromocytoma, carcinoid, flushing disorders), cardiovascular (such as postural orthostatic tachycardia syndrome), and psychiatric conditions (such as a panic disorder and somatoform disorder) may present with similar findings, and therefore should be considered in differential diagnosis.

Hidden allergens have been a matter of debate in the etiology of IA [47-49]. However, to the authors' experience, these are not common causes of IA, but they should be considered in patients, in particular, when an anaphylactic episode was suspected after recent meal by evaluating the ingredients [50•]. We will further review some of the conditions to be considered in the work-up in detail below.

\section{MCAS and Mastocytosis}

As mentioned above, there is an intriguing relationship between IA and MCAS and mastocytosis. Because clonal mast cell disorders can be potentially misdiagnosed as IA, it is, therefore, essential to distinguish them from IA. Akin et al. $[11 \bullet \cdot$ reported presence of a clonal MC population in 5 out of 12 patients with IA in whom there were no features of urticaria pigmentosa or histological evidence for SM on bone marrow biopsies performed locally outside of a mast cell disease referral center. Likewise, Gulen et al. [12] performed bone marrow examination in 30 cases of IA with no signs of cutaneous mastocytosis to look for evidence of clonal MC population, and also to try to identify predictive markers that can possibly distinguish between different IA phenotypes. They reported that $47 \%$ of IA patients were found to have an aberrant $\mathrm{MC}$ population and were subsequently diagnosed with clonal $\mathrm{MC}$ disorder. Finally, a recent study investigated 56 subjects with unexplained anaphylaxis, who had more than three episodes/ year, with BM examination and found evidence of MC clonal disease in $14 \%$ of cases [13•]. The main reason for this discrepancy may be due to the patient selection criteria when diagnosing IA.

There is an unmet need for developing robust criteria to select IA patients for bone-marrow examination in cases of suspected clonal MC disorders. Hence, the search for predictive factors is crucial. In this regard, the Spanish Network on Mastocytosis (Red Española de Mastocitosis [REMA]) proposed a scoring tool [51]. This model is based on a combined clinical (i.e., gender and clinical symptoms) and laboratory (baseline tryptase value with "cut-off" values of $<15$ or $>$ $25 \mathrm{ng} / \mathrm{mL}$ ) criteria, to predict underlying $\mathrm{MC}$ clonality in patients presenting with anaphylaxis [51] (Table 2). A modification of the "REMA-score" has been later proposed as the "Karolinska-score," using a baseline serum tryptase "cut- 
Table 1 Organ-based symptoms of idiopathic anaphylaxis attributable to release of mast cell mediators and potential therapeutics

\begin{tabular}{|c|c|c|}
\hline Clinical features & Attributed mediators & Possible therapeutic interventions \\
\hline $\begin{array}{l}\text { Cardiovascular } \\
\text { Hypotension } \\
\text { Syncope } \\
\text { Tachycardia } \\
\text { Light-headedness }\end{array}$ & $\begin{array}{l}\text { Histamine, PAF, PGD2, cysteinyl LTs, } \\
\text { TNF, tryptase, renin, chymase }\end{array}$ & $\begin{array}{l}\text { In emergency: intramuscular } \\
\quad \text { epinephrine } \\
\text { In prevention: } \\
\text { H1R- and H2R-antihistamines } \\
\text { Antileukotrienes } \\
\text { Prednisone } \\
\text { Omalizumab }\end{array}$ \\
\hline $\begin{array}{l}\text { Cutaneous } \\
\text { Flushing } \\
\text { Pruritus } \\
\text { Urticaria } \\
\text { Angioedema }\end{array}$ & $\begin{array}{l}\text { Histamine, PAF, PGD2, } \\
\text { cysteinyl LTs, TNF }\end{array}$ & $\begin{array}{l}\text { H1R- and H2R-antihistamines } \\
\text { Ketotifen } \\
\text { Aspirin or NSAID }\end{array}$ \\
\hline $\begin{array}{l}\text { Respiratory } \\
\text { Shortness of breath } \\
\text { Wheezing } \\
\text { Inspiratory stridor } \\
\text { Hypoxia }\end{array}$ & $\begin{array}{l}\text { Histamine, PGD2, } \\
\text { cysteinyl LTs, PAF }\end{array}$ & $\begin{array}{l}\text { Antileukotrienes } \\
\text { Inhalation steroids - if asthma } \\
\text { diagnosed } \\
\text { H1R-antihistamines }\end{array}$ \\
\hline $\begin{array}{l}\text { Digestive } \\
\text { Abdominal cramps } \\
\text { Diarrhea } \\
\text { Vomiting }\end{array}$ & $\begin{array}{l}\text { Histamine, PGD2, TNF, } \\
\text { cysteinyl LTs, PAF, } \\
\text { tryptase, serotonin, }\end{array}$ & $\begin{array}{l}\text { H2R-antihistamines } \\
\text { Cromolyn sodium } \\
\quad \text { (oral formulation) } \\
\text { Glucocorticoids }\end{array}$ \\
\hline
\end{tabular}

$P G D_{2}$, prostaglandin $\mathrm{D}_{2} ; L T$, leukotrienes; $P A F$, platelet activation factor; $T N F$, tumor necrosis factor; $H 1 R$, histamine-1-receptor; $H 2 R$, histamine-2-receptor; NSAID, non-steroidal anti-inflammatory drugs off" value of 11.4-20 ng/ml [12] (Table 2). This modified version resulted in a better sensitivity (93\%) and specificity (94\%), when retrospectively applied to their study cohort. Finally, a further improvement of previous tools was proposed, so-called the NIH Idiopathic Clonal Anaphylaxis Score (NICAS), by using clinical symptoms, gender, a baseline tryptase "cut-off" of $11.4 \mathrm{ng} / \mathrm{ml}$, and allele-specific PCR testing to detect the presence or absence of KIT D816V mutation in peripheral blood [13•].

Hereditary alpha-tryptasemia $(\mathrm{H} \alpha \mathrm{T})$ is an autosomal dominant inherited genomic variant of uncertain significance caused by duplication or multiple copy numbers of the $\alpha$ tryptase gene (TPSAB1) copy number and increased numbers of MCs in bone marrow biopsy specimens [52, 53•] but generally does not have increased urinary secretion of other mast cell mediators. $\mathrm{H} \alpha \mathrm{T}$ is reported in approximately $6 \%$ of the general population, in which $\mathrm{SBT}$ levels are typically greater than $8.0 \mathrm{ng} / \mathrm{ml}[53 \cdot, 54]$. These patients may present with a clinical phenotype including Ehlers-Danlos syndrome-like symptoms of joint hypermobility with arthritis, postural orthostatic tachycardia syndrome (POTS), flushing or gastrointestinal hypomotility, vibratory urticaria, irritable bowel syndrome, eosinophilic esophagitis, neuropsychiatric diagnoses, chronic musculoskeletal pain, and allergic disorders affecting the cutaneous, respiratory, or cardiovascular systems $[52,53 \bullet$, $55,56]$; however, this may be subject to referral bias and there has not been consistency in clinical phenotype in unselected cohorts. The etiology of the symptom complex that have been associated with $\mathrm{H} \alpha \mathrm{T}$ remains unknown. The risk for severe spontaneous or/and insect venom-triggered anaphylaxis episodes in $\mathrm{H} \alpha \mathrm{T}$ patients was reported to be increased [57-59]. Interestingly, a recent study reported that increased germline copies of $\alpha$-tryptase are associated with increased severity of venom anaphylaxis and are more prevalent among individuals with idiopathic anaphylaxis and SM, and are associated with an increased relative risk for anaphylaxis among patients with SM [59]. Thus, $\mathrm{H} \alpha \mathrm{T}$ may confer an increased risk for severe anaphylaxis which is independent of the presence of concomitant clonal mast cell disorders. These findings need to be confirmed in larger patient cohorts, and to date, no studies have shown that mast cells in patients with $\mathrm{H} \alpha \mathrm{T}$ are hyperresponsive.

\section{Alpha-gal Syndrome}

Recent research has demonstrated an increasing prevalence mammalian of red meat allergy and anaphylaxis triggered by exposure to a mammalian oligosaccharide, galactose- $\alpha-1,3-$ 
Table 2 Scoring tools to evaluate IA patients for bone-marrow examination in cases of suspected clonal mast cell disorders

\begin{tabular}{llllll}
\hline Variables & \multicolumn{2}{l}{ REMA-score } & & \multicolumn{2}{l}{ Karolinska-score } \\
\cline { 2 - 3 } \cline { 5 - 6 } & Yes & No & & Yes & No \\
\hline Gender & & & & \\
Male & 1 & -1 & 1 & -1 \\
Clinical symptoms & & & & \\
Urticaria/Angioedema & -2 & 1 & -2 & 1 \\
Pruritus & -2 & 1 & -2 & 1 \\
Flushing & $\mathrm{n} / \mathrm{a}$ & $\mathrm{n} / \mathrm{a}$ & $\mathrm{n} / \mathrm{a}$ & $\mathrm{n} / \mathrm{a}$ \\
Syncope & 3 & 0 & 3 & 0 \\
Baseline tryptase & & & & \\
$\leq 11.4 \mathrm{ng} / \mathrm{ml}$ & $\mathrm{n} / \mathrm{a}$ & $\mathrm{n} / \mathrm{a}$ & -1 & $\mathrm{n} / \mathrm{a}$ \\
$11.4-20 \mathrm{ng} / \mathrm{ml}$ & $\mathrm{n} / \mathrm{a}$ & $\mathrm{n} / \mathrm{a}$ & 0 & $\mathrm{n} / \mathrm{a}$ \\
$>20 \mathrm{ng} / \mathrm{ml}$ & $\mathrm{n} / \mathrm{a}$ & $\mathrm{n} / \mathrm{a}$ & 2 & $\mathrm{n} / \mathrm{a}$ \\
$<15 \mathrm{ng} / \mathrm{ml}$ & -1 & $\mathrm{n} / \mathrm{a}$ & $\mathrm{n} / \mathrm{a}$ & $\mathrm{n} / \mathrm{a}$ \\
$15-25 \mathrm{ng} / \mathrm{ml}$ & 0 & $\mathrm{n} / \mathrm{a}$ & $\mathrm{n} / \mathrm{a}$ & $\mathrm{n} / \mathrm{a}$ \\
$>25 \mathrm{ng} / \mathrm{ml}$ & 2 & $\mathrm{n} / \mathrm{a}$ & $\mathrm{n} / \mathrm{a}$ & $\mathrm{n} / \mathrm{a}$ \\
Total score* & $\geq 2$ points & & $\geq 2$ points & \\
Outcome & High risk & & High risk & \\
\hline
\end{tabular}

Modified from Refs. [12, 51]

REMA, Red Española de Mastocitosis; $n / a$, non-applicable

*The sum of positive and negative points of $\geq 2$ is considered to be positive and indicates a high probability for underlying clonal MC disorders, thereby warranting a bone marrow examination

galactose $(\alpha$-gal) [60•]. Thus, some patients previously carrying the label of IA have now been diagnosed with $\alpha$-gal syndrome. Unlike other typical IgE-mediated reactions to food, mammalian meat allergy can manifest with symptoms that are delayed up to $6 \mathrm{~h}$ after ingestion [60॰]. The delayed response is thought to be associated with the digestive process needed to expose the carbohydrate epitope [61]. However, factors such as exercise, alcohol, or aspirin may lower the threshold of responsiveness to $\alpha$-gal [62]. The time span between food consumption and symptoms likely masked the etiology of anaphylaxis and some patients mislabeled as IA prior to the discovery of $\alpha$-gal [63]. Interestingly, in a study with 70 patients who were previously diagnosed with IA, a further evaluation showed that 6 of the patients (of whom two had mastocytosis) had indeed reactions related to $\alpha$-gal sensitization [64•].

In the general adult population, the prevalence of a-gal sensitization ranges between 5.5 and $8.1 \%$ in an urban environment [65]. Interestingly, the overall prevalence of $\alpha$-galsIgE-sensitivity was reported to be $20 \%(\geq 0.10 \mathrm{kU} / \mathrm{L})$ in patients consulting an Allergy Unit, and the highest prevalence $(30.2 \%)$ was found in patients with insect venom allergies [66•]. Additionally, reported tick bite within the 12 months prior to blood sampling significantly increased the risk of $\alpha$ -
gal-sIgE positivity [66॰]. Moreover, another study investigated the overall prevalence of $\alpha$-gal sensitization in patients with clonal MC disorders and found $18 \%$, which appears to be comparable with those of the general population [67]. However, we should keep in mind that not all sensitized patients will experience clinical symptoms; thus, the diagnostic value of $\alpha$-gal-sIgE needs yet to be clarified.

Food-dependent exercise-induced anaphylaxis (FDEIA) should also be considered in differential diagnosis of IA. These reactions may typically begin at any stage of exercise or after just completing exercise, and it is important to know whether or not food ingestion is related to the anaphylactic episodes [68]. Wheat and nuts are the most common culprit foods in Western countries, but shellfish, fruits, vegetables, seeds, legumes, meats, milk, and eggs have all been reported in cases of FDEIA [69-76]. Testing for SIgE to $\omega-5$ gliadin should be considered in patients with suspected wheatdependent exercise-induced anaphylaxis [77]. The diagnosis often needs to be confirmed with a positive exercise challenge; however, a negative exercise challenge does not exclude FDEIA as illustrated by a literature review of 234 cases of FDEIA patients where food/exercise challenges were performed for 81 patients with $36 \%$ of these patients having a negative challenge [78].

\section{Somatoform Conditions}

A group of patients describing subjective symptoms that are consistent with IA without documented objective signs and symptoms have been described and termed to have undifferentiated somatoform IA [79]. Such patients can suffer from panic attacks, vocal cord dysfunction, or Munchausen and can utilize the emergency department repeatedly, for instance, by reporting a sensation of throat tightness (i.e., globus sensation). It may be very challenging to manage these patients, and it is important to evaluate symptoms during acute episodes to confirm whether the reported findings can be documented by a physical examination or an elevation in tryptase or other validated mast cell activation marker during the episode.

\section{Clinical Vignette}

A 68-year-old man without underlying atopies and IgEmediated food allergies was referred to Allergy Outpatient Clinic at Karolinska Hospital in Stockholm, Sweden, due to 11 unexplained spells attributed to MC activation and MC mediator release. On one occasion, he had an anaphylactic reaction where he had syncope. Patient then became flushed all over the body and had swelling of the wrists. He was sweating before he had diarrhea and fainted shortly after. During other occasions, his reactions followed a typical 
pattern of itching, flushing, palpitations, abdominal cramps, and diarrhea.

Patient had a baseline tryptase levels of $15 \mathrm{ng} / \mathrm{ml}$. A bone marrow examination was performed but ruled out underlying clonal MC disorders. However, on two of the symptomatic episodes, he sought emergency care and then it was possible to confirm tryptase elevation as the patient had 31 vs. $35 \mathrm{ng} / \mathrm{ml}$, respectively. Thereby, the patient's symptom patterns and dynamics in his tryptase levels have suggested an underlying systemic mast cell activation process. He was then recommended regular treatment with Desloratadine tablet ${ }^{\circledR}$ ( $5 \mathrm{mg} \times 3$ times daily) and Montelukast $®(10 \mathrm{mg} \times 1$ daily) Most of the patient's symptoms had resolved, and during the recent years, he did not experience any severe reaction. Consequently, the diagnosis of idiopathic MCAS was made.

\section{Management}

Although IA episodes can be potentially life-threatening, the frequency and severity of episodes tend to decrease over time [20], as the vast majority of patients have a benign and gradually improving course $[80,81]$. Treatment of acute episodes of IA is managed similar to other forms of anaphylaxis, with epinephrine administration being of paramount importance. Evidence suggests that treatment of systemic reactions with epinephrine prevents progression to more severe symptoms $[17,33,82]$.

The long-term management for IA aims to reduce the severity and/or frequency of the acute anaphylactic episodes. Nevertheless, evidence for the successful prevention of IA episodes is mainly based on anecdotal case reports for most of the treatment options, as no randomized studies exist to show what treatment(s) are superior in these patients. Hence, we recommend a stepwise approach and management plan to be tailored on a case-by-case basis under close monitoring $[33,50 \bullet, 83]$.

The first step includes H1-histamine receptor antagonists. Doses can be adjusted individually and can be used up to four times similar to those in patients with chronic urticaria. H2histamine receptor antagonists, antileukotrienes can be additionally given in unresponsive patients. Steroids are typically not required in those with less frequent IA attacks; however, the long-term use of corticosteroids may be necessary in patients with recurrent episodes (> 5/year) [19, 22, 84]. Typical regimens for adults start from 40 to $60 \mathrm{mg}$ prednisone daily and taper the dose by 5 to $10 \mathrm{mg}$ every 2 weeks [19]. In these patients, the lowest dose of steroid capable of preventing anaphylaxis should be considered. The efficacy of the combination of steroids and H1-histamine receptor antagonists can be estimated from case reports and observational series [19, 38]. In the largest published series, 132 of 335 patients were available at the time of data collection [19]. Eighty-seven were in remission, and the duration of remission ranged from 1 to 14 years. Prednisone for frequent episodes had been administered to 56 patients, and approximately $20 \%$ had recurrent symptoms as the prednisone was tapered. Among those who eventually weaned off it, the duration of alternate day therapy was 3 months to 13 years.

Steroid-sparing alternatives, including omalizumab, should be considered in patients with recurrent episodes if the combination therapies are ineffective or due to the comorbidity associated with their long-term use. Omalizumab, a monoclonal antibody directed against $\operatorname{IgE}$, has been reported to reduce the frequency of IA episodes in anecdotal reports and case series with varying success [12, 85-87]. However, omalizumab, as all the others, is not a curative therapy and there are currently no randomized, placebo-controlled studies to recommend its routine use.

There are additional therapies that may be beneficial as an "add-on" treatment in some cases. These include ketotifen, and oral cromolyn. Ketotifen is an H1 antihistamine receptor antagonists /mast cell stabilizer that can cause significant sedation. The oral formulation of ketotifen is not approved for use in the USA but the drug can be compounded. Steroid sparing evidence has been published using ketotifen in IA [88-90], and its mast cell stabilizing properties have also been demonstrated in mastocytosis $[91,92]$. The usual dose is $1-$ $2 \mathrm{mg}$ orally two or three times per day. Oral cromolyn, which has also local mast cell stabilizing property, can be helpful for patients with prominent gastrointestinal symptoms [19]; however, little is absorbed to systemic circulation, limiting its value as a prophylactic therapy of systemic symptoms. Additionally, some patients do not tolerate this medication because of bloating, cramping, and diarrhea.

\section{Conclusion}

IA is a diagnosis of exclusion and presents with signs and symptoms due to the paroxysmal release of mast cell mediators. During recent years, our understanding of IA has evolved with the recognition of mast cell activation syndromes, mastocytosis, IgE to $\alpha$-gal or $\Omega$-5-gliadin, and certain medications as causes of anaphylaxis. Management consists of using medications such as antihistamines, sympathomimetic agents, prednisone, and omalizumab. Although there are many unresolved issues regarding the epidemiology and pathogenesis of IA, there are some available evidence to support a mast cell-dependent mechanism which include elevations in tryptase and histamine levels during acute episodes. Thus, these findings support the notion that IA should be considered a form of mast cell activation disorder. Further understanding of the intrinsic changes in mast cells of patients with IA will be an important aspect to address as this area of research continues. 
Funding Open Access funding provided by Karolinska Institute. This study was supported by grants from the Konsul TH C Bergh Foundation, Sweden, and through the regional agreement on medical training and clinical research (ALF) between Stockholm County Council and Karolinska Institutet.

\section{Compliance with Ethical Standards}

Conflict of Interest T. Gülen has received lecture fees from Thermo Fisher. C. Akin has received consultancy fees from Blueprint Medicines and Novartis and has a patent for LAD2 cells.

Human and Animal Rights and Informed Consent This article does not contain any studies with human or animal subjects performed by any of the authors.

Open Access This article is licensed under a Creative Commons Attribution 4.0 International License, which permits use, sharing, adaptation, distribution and reproduction in any medium or format, as long as you give appropriate credit to the original author(s) and the source, provide a link to the Creative Commons licence, and indicate if changes were made. The images or other third party material in this article are included in the article's Creative Commons licence, unless indicated otherwise in a credit line to the material. If material is not included in the article's Creative Commons licence and your intended use is not permitted by statutory regulation or exceeds the permitted use, you will need to obtain permission directly from the copyright holder. To view a copy of this licence, visit http://creativecommons.org/licenses/by/4.0/.

\section{References}

Papers of particular interest, published recently, have been highlighted as:

- Of importance

•- Of major importance

1. Galli SJ, Kalesnikoff J, Grimbaldeston MA, Piliponsky AM, Williams CM, Tsai M. Mast cells as "tunable" effector and immunoregulatory cells: recent advances. Annu Rev Immunol. 2005;23: 749-86.

2. Valent P, Akin C, Hartmann K, Nilsson G, Reiter A, Hermine O, et al. Mast cells as a unique hematopoietic lineage and cell system: from Paul Ehrlich's visions to precision medicine concepts. Theranostics. 2020;10(23):10743-68.

3. Varricchi G, Marone G. Mast cells: fascinating but still elusive after 140 years from their discovery. Int J Mol Sci. 2020;21(2):464.

4. Galli SJ, Tsai M. Mast cells in allergy and infection: versatile effector and regulatory cells in innate and adaptive immunity. Eur J Immunol. 2010;40(7):1843-51.

5. Iwaki S, Spicka J, Tkaczyk C, Jensen BM, Furumoto Y, Charles N, et al. Kit- and fc epsilonRI-induced differential phosphorylation of the transmembrane adaptor molecule NTAL/LAB/LAT2 allows flexibility in its scaffolding function in mast cells. Cell Signal. 2008;20(1):195-205.

6. Kelso JM. MRGPRX2 signaling and skin test results. J Allergy Clin Immunol Pract. 2020;8(1):426.

7. Gilfillan AM, Beaven MA. Regulation of mast cell responses in health and disease. Crit Rev Immunol. 2011;31(6):475-529.

8. Castells M. Mast cell mediators in allergic inflammation and mastocytosis. Immunol Allergy Clin N Am. 2006;26(3):465-85.
9. Bacal E, Patterson R, Zeiss CR. Evaluation of severe (anaphylactic) reactions. Clin Allergy. 1978;8(3):295-304.

10. Sampson HA, Munoz-Furlong A, Campbell RL, Adkinson NF Jr, Bock SA, Branum A, et al. Second symposium on the definition and management of anaphylaxis: summary report-second National Institute of Allergy and Infectious Disease/Food Allergy and Anaphylaxis Network symposium. Ann Emerg Med. 2006;47(4): 373-80.

11.• Akin C, Scott LM, Kocabas CN, Kushnir-Sukhov N, Brittain E, Noel $\mathrm{P}$, et al. Demonstration of an aberrant mast-cell population with clonal markers in a subset of patients with "idiopathic" anaphylaxis. Blood. 2007;110(7):2331-3 First demonstration that clonal mast cell disease can be underlying in patients formerly diagnosed as IA.

12. Gulen T, Hagglund H, Sander B, Dahlen B, Nilsson G. The presence of mast cell clonality in patients with unexplained anaphylaxis. Clin Exp Allergy. 2014;44(9):1179-87.

13. Carter MC, Desai A, Komarow HD, Bai Y, Clayton ST, Clark AS, et al. A distinct biomolecular profile identifies monoclonal mast cell disorders in patients with idiopathic anaphylaxis. J Allergy Clin Immunol. 2018;141(1):180-8.e3 This study explores in-depth clinical and laboratory features of idiopathic anaphylaxis and suggests a risk scoring tool that can be used to select idiopathic anaphylaxis patients who more likely to have an underlying clonal mast cell disorder and thus candidates for a bone marrow biopsy.

14. Panesar SS, Javad S, de Silva D, Nwaru BI, Hickstein L, Muraro A, et al. The epidemiology of anaphylaxis in Europe: a systematic review. Allergy. 2013;68(11):1353-61.

15. Wood RA, Camargo CA Jr, Lieberman P, Sampson HA, Schwartz LB, Zitt M, et al. Anaphylaxis in America: the prevalence and characteristics of anaphylaxis in the United States. J Allergy Clin Immunol. 2014;133(2):461-7.

16. Patterson R, Hogan MB, Yarnold PR, Harris KE. Idiopathic anaphylaxis. An attempt to estimate the incidence in the United States. Arch Intern Med. 1995;155(8):869-71.

17. Lieberman PL. Idiopathic anaphylaxis. Allergy Asthma Proc. 2014;35(1):17-23.

18. Kemp SF, Lockey RF, Wolf BL, Lieberman P. Anaphylaxis. A review of 266 cases. Arch Intern Med. 1995;155(16):1749-54.

19. Ditto AM, Harris KE, Krasnick J, Miller MA, Patterson R. Idiopathic anaphylaxis: a series of 335 cases. Ann Allergy Asthma Immunol. 1996;77(4):285-91.

20. Webb LM, Lieberman P. Anaphylaxis: a review of 601 cases. Ann Allergy Asthma Immunol. 2006;97(1):39-43.

21. Moneret-Vautrin DA, Gay G. The so-called "idiopathic" anaphylaxis: allergic and pseudo-allergic reactions. Allerg Immunol (Paris). 1991;23(3):89-93.

22. Ditto AM, Krasnick J, Greenberger PA, Kelly KJ, McGrath K, Patterson R. Pediatric idiopathic anaphylaxis: experience with 22 patients. J Allergy Clin Immunol. 1997;100(3):320-6.

23. Tejedor Alonso MA, Sastre Dominguez J, Sanchez-Hernandez JJ, PerezFrances C, Hoz de la Caballer B. Clinical and functional differences among patients with idiopathic anaphylaxis. J Investig Allergol Clin Immunol. 2004;14(3):177-86.

24. Grammer LC, Shaughnessy MA, Harris KE, Goolsby CL. Lymphocyte subsets and activation markers in patients with acute episodes of idiopathic anaphylaxis. Ann Allergy Asthma Immunol. 2000;85(5):368-71.

25. Akin C, Schwartz LB, Kitoh T, Obayashi H, Worobec AS, Scott LM, et al. Soluble stem cell factor receptor (CD117) and IL-2 receptor alpha chain $(\mathrm{CD} 25)$ levels in the plasma of patients with mastocytosis: relationships to disease severity and bone marrow pathology. Blood. 2000;96(4):1267-73. 
26. Slater JE, Kaliner M. Effects of sex hormones on basophil histamine release in recurrent idiopathic anaphylaxis. J Allergy Clin Immunol. 1987;80(3 Pt 1):285-90.

27. Hox V, Desai A, Bandara G, Gilfillan AM, Metcalfe DD, Olivera A. Estrogen increases the severity of anaphylaxis in female mice through enhanced endothelial nitric oxide synthase expression and nitric oxide production. J Allergy Clin Immunol. 2015;135(3):72936.e5.

28. Howell D, Jacobs C, Metz G, Rhodd C, Zhang J, Dave S, et al. Molecular profiling distinguishes patients with active idiopathic anaphylaxis from Normal volunteers and reveals novel aspects of disease biology. J Allergy Clin Immunol. 2009;123:S150.

29. Reed J, Yedulapuram M, Lieberman P, Fitzpatrick E. Differences in cytokine production between idiopathic anaphylaxis (IA) subjects and controls. J Allergy Clin Immunol. 2006;117(2):S305.

30. Akin C. Mast cell activation syndromes presenting as anaphylaxis. Immunol Allergy Clin N Am. 2015;35(2):277-85.

31. Akin C. Mast cell activation syndromes. J Allergy Clin Immunol. 2017;140(2):349-55.

32. Giannetti MP, Akin C, Castells M. Idiopathic anaphylaxis: a form of mast cell activation syndrome. J Allergy Clin Immunol Pract. 2020;8(4):1196-201.

33. Greenberger PA, Lieberman P. Idiopathic anaphylaxis. J Allergy Clin Immunol Pract. 2014;2(3):243-50 quiz 51.

34. Jönsson F, Mancardi DA, Albanesi M, Bruhns P. Neutrophils in local and systemic antibody-dependent inflammatory and anaphylactic reactions. J Leukoc Biol. 2013;94(4):643-56.

35. Beutier H, Gillis CM, Iannascoli B, Godon O, England P, Sibilano $\mathrm{R}$, et al. IgG subclasses determine pathways of anaphylaxis in mice. J Allergy Clin Immunol. 2017;139(1):269-80.e7.

36. Shanmugam G, Schwartz LB, Khan DA. Prolonged elevation of serum tryptase in idiopathic anaphylaxis. J Allergy Clin Immunol. 2006;117(4):950-1.

37. Tanus T, Mines D, Atkins PC, Levinson AI. Serum tryptase in idiopathic anaphylaxis: a case report and review of the literature. Ann Emerg Med. 1994;24(1):104-7.

38. Boxer MB, Greenberger PA, Patterson R. The impact of prednisone in life-threatening idiopathic anaphylaxis: reduction in acute episodes and medical costs. Ann Allergy. 1989;62(3):201-4.

39. Gulen T, Hagglund H, Dahlen B, Nilsson G. Mastocytosis: the puzzling clinical spectrum and challenging diagnostic aspects of an enigmatic disease. J Intern Med. 2016;279(3):211-28.

40. Valent P, Akin C, Metcalfe DD. Mastocytosis 2016: Updated WHO classification and novel emerging treatment concepts. Blood. 2016;129(11):1420-7.

41. Gulen T, Hagglund H, Dahlen B, Nilsson G. High prevalence of anaphylaxis in patients with systemic mastocytosis - a single-centre experience. Clin Exp Allergy. 2014;44(1):121-9.

42. Brockow K, Jofer C, Behrendt H, Ring J. Anaphylaxis in patients with mastocytosis: a study on history, clinical features and risk factors in 120 patients. Allergy. 2008;63(2):226-32.

43. Akin C, Valent P, Metcalfe DD. Mast cell activation syndrome: proposed diagnostic criteria. J Allergy Clin Immunol. 2010;126(6):1099-U60.

44. Valent P, Akin C, Arock M, Brockow K, Butterfield JH, Carter $\mathrm{MC}$, et al. Definitions, criteria and global classification of mast cell disorders with special reference to mast cell activation syndromes: a consensus proposal. Int Arch Allergy Immunol. 2012;157(3):21525.

45. Valent $\mathrm{P}$, Akin $\mathrm{C}$, Bonadonna $\mathrm{P}$, Hartmann $\mathrm{K}$, Brockow $\mathrm{K}$, Niedoszytko M, et al. Proposed diagnostic algorithm for patients with suspected mast cell activation syndrome. J Allergy Clin Immunol Pract. 2019;7(4):1125-33.e1.

46. Gulen T, Hagglund H, Dahlen SE, Sander B, Dahlen B, Nilsson G. Flushing, fatigue, and recurrent anaphylaxis: a delayed diagnosis of mastocytosis. Lancet. 2014;383(9928):1608.
47. Sonin L, Patterson R. Metabisulfite challenge in patients with idiopathic anaphylaxis. J Allergy Clin Immunol. 1985;75(1 Pt 1):67-9.

48. Añíbarro B, Seoane FJ, Múgica MV. Involvement of hidden allergens in food allergic reactions. J Investig Allergol Clin Immunol. 2007;17(3):168-72.

49. Baker MG, Saf S, Tsuang A, Nowak-Wegrzyn A. Hidden allergens in food allergy. Ann Allergy Asthma Immunol. 2018;121(3):28592 .

50. Carter MC, Akin C, Castells MC, Scott EP, Lieberman P. Idiopathic anaphylaxis yardstick: practical recommendations for clinical practice. Ann Allergy Asthma Immunol. 2020;124(1):1627 A comprehensive review that focuses on all practical issues in patients with idiopathic anaphylaxis including its diagnostic and management.

51. Alvarez-Twose I, Gonzalez de Olano D, Sanchez-Munoz L, Matito A, Esteban-Lopez MI, Vega A, et al. Clinical, biological, and molecular characteristics of clonal mast cell disorders presenting with systemic mast cell activation symptoms. J Allergy Clin Immunol. 2010;125(6):1269-78 e2.

52. Lyons JJ, Sun G, Stone KD, Nelson C, Wisch L, O'Brien M, et al. Mendelian inheritance of elevated serum tryptase associated with atopy and connective tissue abnormalities. J Allergy Clin Immunol. 2014;133(5):1471-4.

53. - Lyons JJ, Yu X, Hughes JD, Le QT, Jamil A, Bai Y, et al. Elevated basal serum tryptase identifies a multisystem disorder associated with increased TPSAB1 copy number. Nat Genet. 2016;48(12): $1564-9$.

54. Robey RC, Wilcock A, Bonin H, Beaman G, Myers B, Grattan C, et al. Hereditary alpha-tryptasemia: UK Prevalence and variability in disease expression. J Allergy Clin Immunol Pract. 2020;8(10): 3549-56.

55. Lyons JJ. Hereditary alpha Tryptasemia: genotyping and associated clinical features. Immunol Allergy Clin N Am. 2018;38(3):483-95.

56. Khoury P, Lyons JJ. Mast cell activation in the context of elevated basal serum tryptase: genetics and presentations. Curr Allergy Asthma Rep. 2019;19(12):55.

57. O'Connell MP, Lyons JJ. Hymenoptera venom-induced anaphylaxis and hereditary alpha-tryptasemia. Curr Opin Allergy Clin Immunol. 2020;20(5):431-7.

58. Lyons JJ, Chovanec J, O'Connell MP, Liu Y, Šelb J, Zanotti R, et al. Heritable risk for severe anaphylaxis associated with increased $\alpha$-tryptase-encoding germline copy number at TPSAB1. J Allergy Clin Immunol. 2020:S0091-6749(20)31029-0. https://doi.org/10. 1016/j.jaci.2020.06.035 Online ahead of print.

59. Greiner G, Sprinzl B, Górska A, Ratzinger F, Gurbisz M, Witzeneder N, et al. Hereditary alpha tryptasemia is a valid genetic biomarker for severe mediator-related symptoms in mastocytosis. Blood. 2020:blood.2020006157. https://doi.org/10.1182/blood. 2020006157 Online ahead of print.

60. Commins SP, Platts-Mills TA. Anaphylaxis syndromes related to a new mammalian cross-reactive carbohydrate determinant. J Allergy Clin Immunol. 2009;124(4):652-7.

61. Steinke JW, Platts-Mills TA, Commins SP. The alpha-gal story: lessons learned from connecting the dots. J Allergy Clin Immunol. 2015;135(3):589-96 quiz 97.

62. Fischer J, Yazdi AS, Biedermann T. Clinical spectrum of $\alpha$-gal syndrome: from immediate-type to delayed immediate-type reactions to mammalian innards and meat. Allergo J Int. 2016;25:5562.

63. Tripathi A, Commins SP, Heymann PW, Platts-Mills TAE. Delayed anaphylaxis to red meat masquerading as idiopathic anaphylaxis. J Allergy Clin Immunol Pract. 2014;2(3):259-65.

64. Carter MC, Ruiz-Esteves KN, Workman L, Lieberman P, PlattsMills TAE, Metcalfe DD. Identification of alpha-gal sensitivity in patients with a diagnosis of idiopathic anaphylaxis. Allergy. 2018;73(5):1131-4 This study highlights that patients with 
alpha-gal syndrome can be underlying diagnosis in some patients $(9 \%)$ who were previously labelled as idiopathic anaphylaxis.

65. Gonzalez-Quintela A, Dam Laursen AS, Vidal C, Skaaby T, Gude F, Linneberg A. IgE antibodies to alpha-gal in the general adult population: relationship with tick bites, atopy, and cat ownership. Clin Exp Allergy. 2014;44(8):1061-8.

66. Fischer J, Huynh HN, Hebsaker J, Forchhammer S, Yazdi AS. Prevalence and impact of type i sensitization to alpha-gal in patients consulting an allergy unit. Int Arch Allergy Immunol. 2020;181(2): 119-27 Study highlighting the increased prevalence of alphagal sensitization in patients seeking allergists; however, not many of those have a clinically relevant sensitization.

67. Jarkvist J, Brockow K, Gülen T. Low frequency of IgE-mediated food hypersensitivity in Mastocytosis. J Allergy Clin Immunol Pract. 2020;8:3093-101

68. Farrell A, Judge C, Redenbaugh V, Awad H, Conlon N. Fooddependent exercise-induced reactions: lessons from a 15-year retrospective study. Ir J Med Sci. 2019;188(3):815-9.

69. Asero R, Mistrello G, Roncarolo D, Antoniotti P, Falagiani P. Exercise-induced egg anaphylaxis. Allergy. 1997;52(6):687-9.

70. Beaudouin E, Renaudin JM, Morisset M, Codreanu F, Kanny G, Moneret-Vautrin DA. Food-dependent exercise-induced anaphylaxis-update and current data. Eur Ann Allergy Clin Immunol. 2006;38(2):45-51.

71. Bito T, Kanda E, Tanaka M, Fukunaga A, Horikawa T, Nishigori C. Cows milk-dependent exercise-induced anaphylaxis under the condition of a premenstrual or ovulatory phase following skin sensitization. Allergol Int. 2008;57(4):437-9.

72. Fujii H, Kambe N, Fujisawa A, Kohno K, Morita E, Miyachi Y. Food-dependent exercise-induced anaphylaxis induced by low dose aspirin therapy. Allergol Int. 2008;57(1):97-8.

73. Orhan F, Karakas T. Food-dependent exercise-induced anaphylaxis to lentil and anaphylaxis to chickpea in a 17-year-old boy. J Investig Allergol Clin Immunol. 2008;18(6):465-8.

74. Adachi A, Horikawa T, Shimizu H, Sarayama Y, Ogawa T, Sjolander S, et al. Soybean beta-conglycinin as the main allergen in a patient with food-dependent exercise-induced anaphylaxis by tofu: food processing alters pepsin resistance. Clin Exp Allergy. 2009;39(1):167-73.

75. Pastorello EA, Farioli L, Stafylaraki C, Scibilia J, Mirone C, Pravettoni V, et al. Wheat-dependent exercise-induced anaphylaxis caused by a lipid transfer protein and not by $\omega-5$ gliadin. Ann Allergy Asthma Immunol. 2014;112(4):386-7.e1.

76. Hayashi M, Pawankar R, Yamanishi S, Itoh Y. Food-dependent exercise-induced anaphylaxis to soybean: Gly $\mathrm{m} 5$ and Gly $\mathrm{m} 6$ as causative allergen components. World Allergy Organ J. 2020;13(7):100439.
77. Le TA, Al Kindi M, Tan JA, Smith A, Heddle RJ, Kette FE, et al. The clinical spectrum of omega-5-gliadin allergy. Intern Med J. 2016;46(6):710-6.

78. Hanakawa Y, Tohyama M, Shirakata Y, Murakami S, Hashimoto K. Food-dependent exercise-induced anaphylaxis: a case related to the amount of food allergen ingested. Br J Dermatol. 1998;138(5): 898-900.

79. Choy AC, Patterson R, Patterson DR, Grammer LC, Greenberger PA, McGrath KG, et al. Undifferentiated somatoform idiopathic anaphylaxis: nonorganic symptoms mimicking idiopathic anaphylaxis. J Allergy Clin Immunol. 1995;96(6 Pt 1):893-900.

80. Boxer M, Greenberger PA, Patterson R. Clinical summary and course of idiopathic anaphylaxis in 73 patients. Arch Intern Med. 1987;147(2):269-72.

81. Khan DA, Yocum MW. Clinical course of idiopathic anaphylaxis. Ann Allergy. 1994;73(4):370-4.

82. Lieberman PL. Recognition and first-line treatment of anaphylaxis. Am J Med. 2014;127(1 Suppl):S6-S11.

83. Gulen T, Akin C. Pharmacotherapy of mast cell disorders. Curr Opin Allergy Clin Immunol. 2017;17(4):295-303.

84. Wong S, Yarnold PR, Yango C, Patterson R, Harris KE. Outcome of prophylactic therapy for idiopathic anaphylaxis. Ann Intern Med. 1991;114(2):133-6.

85. Jones JD, Marney SR Jr, Fahrenholz JM. Idiopathic anaphylaxis successfully treated with omalizumab. Ann Allergy Asthma Immunol. 2008;101(5):550-1.

86. Warrier P, Casale TB. Omalizumab in idiopathic anaphylaxis. Ann Allergy Asthma Immunol. 2009;102(3):257-8.

87. Kibsgaard L, Skjold T, Deleuran M, Vestergaard C. Omalizumab induced remission of idiopathic anaphylaxis in a patient suffering from indolent systemic mastocytosis. Acta Derm Venereol. 2014;94(3):363-4.

88. Patterson R, Wong S, Dykewicz MS, Harris KE. Malignant idiopathic anaphylaxis. J Allergy Clin Immunol. 1990;85(1 Pt 1):86-8.

89. Wong S, Patterson R, Harris KE, Dykewicz MS. Efficacy of ketotifen in corticosteroid-dependent idiopathic anaphylaxis. Ann Allergy. 1991;67(3):359-64.

90. Dykewicz MS, Wong SS, Patterson R, Harris KE. Evaluation of ketotifen in corticosteroid-dependent idiopathic anaphylaxis. Ann Allergy. 1990;65(5):406-10.

91. Ting S. Ketotifen and systemic mastocytosis. J Allergy Clin Immunol. 1990;85(4):818.

92. Povoa P, Ducla-Soares J, Fernandes A, Palma-Carlos AG. A case of systemic mastocytosis; therapeutic efficacy of ketotifen. J Intern Med. 1991;229(5):475-7.

Publisher's Note Springer Nature remains neutral with regard to jurisdictional claims in published maps and institutional affiliations. 